\title{
USE OF RICE BRAN OIL AS NATURAL ANTIOXIDANT IN WHITE SOFT CHEESE MANUFACTURINE
}

\author{
Ali A. Abd El-Galeel* and E.H. Atwaa \\ Food Sci. Dept., Fac. Agric., Zagazig Univ., Egypt
}

\section{Received: 08/02/2017 ; Accepted: 16/03/2017}

\begin{abstract}
This study was carried out to determine the antioxidant activity and phenolic compounds of rice bran oil, also to evaluate the effect of added rice bran oil on the oxidative stability, microbial and sensory properties of soft cheese (Domiati). Rice bran oil was used in cheese manufacture at ratio of 0.1 and $0.2 \%(W / W)$ compared with cheese with $200 \mathrm{ppm}$ of butylated hydroxyl anisol (BHA). Cheese treatments were stored at room temperature for four months and analyzed for chemical, microbiological, oxidative stability indices and sensory properties when fresh and then after 1, 2, 3 and 4 months of storage. Results showed that rice bran oil contains a high content of phenolic compounds and gave high antioxidant activity. Cheeses containing $0.2 \%$ of rice bran oil showed the highest oxidative stability (lowest in the peroxide, acid and Thiobarbituric acid (TBA) values), recommended better sensory properties and the lowest microbial count than the other treatments. Generally, cheese samples containing natural antioxidant (rice bran oil) showed lower peroxide, acid and TBA values compared with cheese containing BHA and control cheese along the storage period. From the results of this research it could be seen that addition of rice bran oil at a rate of $0.2 \%$ in manufacture of white soft cheese as a natural antioxidant to improve the oxidative stability, bacteriological and sensory quality of the resultant cheese during storage.
\end{abstract}

Key words: Antioxidant activity, phenolic compounds, rice bran oil, natural antioxidant, white soft cheese.

\section{NTRODUCTION}

Antioxidants are major ingredients that protect the quality of oils and fats by retarding oxidation (Jang et al., 2012). Synthetic antioxidants are used at legal limits to reduce deterioration, rancidity and oxidative discoloration (Abdulla et al., 2007). Butylated hydroxy anisol (BHA) and Butylated hydroxy toluene (BHT) are quite volatile and decompose easily at high temperatures (Bandyopadhyay et al., 2007). There are some serious problems concerning the safety and toxicity of such synthetic antioxidants related to their metabolism and possible absorption and accumulation in body organs and tissues (Ajila et al., 2007). Therefore, the search for preparation of useful natural antioxidants is highly desirable. Natural antioxidative compounds are found in numerous plant materials such as oil seeds, cereal crops, vegetables, fruits, leaves, barks and roots, spices and herbs (Yean and Philip, 2004). Many studies showed that natural antioxidants, as flavanoids and other phenolic phytochemical present in plants are associated with reduced chronic disease risk (Bandyopadhyay et al., 2008).

Rice bran oil (RBO) as an excellent source of natural antioxidants, which lowers human blood cholesterol more effectively than sunflower, corn and safflower oils. RBO shows an exceptionally high oxidative stability compared to soybean, palm, sesame, corn and most other popular vegetable oils (Bopitiya and Madhujith, 2014). Rice bran oil based products have extended shelf life since RBO is extremely stable against rancidity and oxidative deterioration (Akiri et al. 2010).

\footnotetext{
*Corresponding author: Tel. : +201065024953

E-mail address: draliabdelgaleel@yahoo.com
} 
Rice bran oil (RBO) is one of the best sources of tocols and oryzanol. Tocols (tocopherols and tocotrienols), a family of vitamin E-active substances, are wildly used as plant-based ingredients in the food, cosmetics and pharmaceutical industries (Abidi, 2003; Pengkumsri et al., 2015). Studies suggested that tocotrienols are more efficient antioxidant, anticancer agent and inhibitor of cholesterol synthesis than the tocopherols (Singh et al., 2013). Gamma-oryzanol is one of the major components of $\mathrm{RBO}$, and it is a mixture of several ferulate esters of triterpene alcohols and plant sterols (Friedman, 2013). Oryzanol is a well-known antioxidant compound and is linked with decreasing serum and plasma cholesterol, decreasing platelet aggregation, and cholesterol absorption. Moreover oryzanol has been used in the treatment of hyperlipidemia, and disorders of menopause (Patel and Naik, 2004).

Soft cheese is one of the most appreciated cheeses in Middle Eastern countries. The cheese is a pickled cheese (salt 2-15\%), although it may be sold fresh. This type of cheese is produced either by enzymatic or acidic coagulation of fresh milk (buffalos' or cows' milk) or reconstituted skim milk powder with oils (Ramadan et al., 2014). It has also been made with or without the addition of starter cultures to cheese milk. Starter cultures govern the flavour and texture of the cheese, and help to suppress the growth of spoilage bacteria.

The present study was planned to measure the antioxidant activity and total phenolic compounds of rice bran oil and evaluation effect of added rice bran oil to white soft cheese to improve its oxidative stability.

\section{MATERIALS AND METHODS}

Fresh buffalo's milk (6\% fat) was obtained from Dairy Technology Unit, Food Science Department, Faculty of Agriculture, Zagazig University, Zagazig, Egypt. Rice bran oil was purchased from local market. Powder animal rennet was obtained from Char-Hansen's Laboratories, Copenhagen, Denmark.

Pure calcium chloride was obtained from ElGomhoria Co., Cairo, Egypt.
Food grade cooking salt $(\mathrm{NaCl})$ was used in soft cheese making. Butylated hydroxyl anisole (BHA) was obtained from BDH chemical Ltd, Poole, and U.K

\section{Determination of Total Phenolic Content}

The concentration of total phenols in rice bran oil was measured by a UV spectrophotometer (Jenway-UV-VIS Spectrophotometer), based on a colorimetric oxidation/reduction reaction, as described by Škerget et al. (2005), with the use of Folin-Ciocalteu's reagent (AOAC, 1990).

\section{Identification of Phenolic Compounds}

Phenolic compounds of the samples were identified according to the method described by Goupy et al. (1999) and Mattila et al. (2000) using HPLC.

\section{Determination of Radical Scavenging Activity}

The electron donation ability of the rice bran oil was measured by bleaching of the purple coloured solution of the 2,2-diphenyl-1picrylhydrazyl radical (DPPH) to shad yellow according to the method of Hatano et al. (1988) as modified by Gulcin et al. (2004).

\section{Cheese Making}

Fresh bulk buffalo's milk containing $6 \%$ fat was pasteurized at $63^{\circ} \mathrm{C}$ for $30 \mathrm{~min}$., calcium chloride and sodium chloride were added at the ratios of $0.02 \%$ and $6 \%(W / V)$ respectively. The treated milk was divided into 4 portions. The first portion was left without any additives and served as a control (C). The BHA as synthetic antioxidant was added to the second portion at ratio of $200 \mathrm{ppm}(\mathrm{C} 1)$. Rice bran oil was added to the other two parts (T1 and T2) at level of 0.1 and $0.2 \%$, respectively. All milk treatments were renneted using $3 \mathrm{~g}$ of animal powder rennet to each $100 \mathrm{Kg}$ cheese milk. Soft cheese treatments were made by the conventional method of making Domiati cheese (Fahmi and Sharara, 1950). Resultant cheeses were put in plastic containers with formerly boiled saline (10\% salt) and stored at room temperature $\left(25 \pm 1^{\circ} \mathrm{C}\right)$ for four months and sampled for analysis when fresh and then after 1, 2, 3 and 4 months of storage. 


\section{Chemical Analysis}

Total solids, fat and total nitrogen (TN) contents of soft cheese samples were determined according to AOAC (2007). The protein content was obtained by multiplying the percentage of $\mathrm{TN}$ by 6.38 . The $\mathrm{pH}$ value was measured using digital $\mathrm{pH}$ meter (HANNA, Instrument, Portugal) with glass electrode. The water soluble nitrogen percent (WSN/TN) was estimated as described by Innocente (1997).

The lipids were extracted from cheese samples using a method described by Kristensen et al. (2001). Acid value of extracted lipids was determined according to AOAC (2007). Peroxide value (PV) of extracted lipids was determined according to the method described by Egan et al. (1981). Thiobarbiuturic acid test (TBA) value was determined according to Keeny (1971).

Total volatile fatty acids (TVFAs) value were determined according to the method described by Kosikowski (1982). Values were expressed as $\mathrm{ml}$ of $0.1 \mathrm{~N} \mathrm{NaOH} / 100 \mathrm{~g}$ cheese.

\section{Microbiological Analysis}

Cheese samples each of $10 \mathrm{~g}$, were taken at the age of $0,1,2,3$ and 4 months, then homogenized in sterile $90 \mathrm{ml}$ of $0.1 \%$ peptone water. Serial 8 fold dilutions in sterile $0.1 \%$ peptone water were prepared for bacterial analysis. Plate count agar medium was used for determining the total bacterial count. Plates were incubated at $37^{\circ} \mathrm{C}$ for 2 days (Houghtby and Matuin, 1992). Potato Dextrose Agar was used for yeast and mould enumeration. Plates were incubated at $25^{\circ} \mathrm{C}$ for 5 days, according to Marshall (1992). Violet Red Bile Agar was used for the enumeration of coliforms. Plates were incubated at $37^{\circ} \mathrm{C}$ for $24 \mathrm{hr}$., according to Marshall (1992).

\section{Sensory Properties of Cheese}

The sensory properties of cheese samples were assessed by 10 panel members of the Dairy Sci., Dep., Fac. Agric., Zagazig, Univ. for flavour (50) body and texture (40) and appearance (10) according to Pappas et al. (1996).

\section{Statistical Analysis}

All data were statistically analyzed using the general linear models procedure of the statistical analysis system SAS (1998). Significances of differences were defined at $p<0.05$. All experiments as well as related analysis results were repeated three times and all obtained data were expressed as an average.

\section{RESULTS AND DISCUSSION}

\section{Total Phenolic Compounds}

Rice bran oil was determined for total phenols (Table 1). The data showed that rice bran oil had the total phenols of $2.35 \mathrm{mg} / \mathrm{g}$. Rice bran oil contains unsaponifiable lipids, which contain a unique complex of naturally occurring antioxidant components, tocopherols, tocotrienols and oryzanol. These compounds have high antioxidative properties. Similar results were reported by Singh et al. (2013).

\section{Radical Scavenging Activity (RSA)}

The results of radical scavenging activity (RSA) assay of rice bran oil shown in (Table 1). The RSA of rice bran oil are showen $74.70 \%$. Tocopherols, tocotrienols and oryzanol that found in rice bran oil are phenolic compounds that acts as primary antioxidants or free radical scavengers. Similar results were reported by Sarmento et al. (2006) and Bopitiya and Madhujith (2014).

Table 1. Total phenolic compounds and radical scavenging activity of rice bran oil (using DPPH radical scavenging as measured by changes at $515 \mathrm{~nm}$ )

\begin{tabular}{lc}
\hline Item & Rice bran oil \\
\hline Total phenolic compound & $2.35(\mathrm{mg} / \mathrm{g})$ \\
Radical scavenging activity (RSA) & $74.70 \%$ \\
\hline
\end{tabular}




\section{Identification of Phenolic Compounds by HPLC}

Table 2 shows the content of phenolic compounds in rice bran oil. There was a great variation in the contents among the components identified in rice bran oil. Phenolic compounds are widely distributed in nature. It is suggested that their antioxidant activity is related to their cingulated rings and hydroxyl groups (Mattila et al., 2000). Phenolic compounds identified in rice bran oil namely tocopherols and tocotrinols were in amount ranging from $0.99-78.40 \mathrm{mg} /$ $100 \mathrm{~g}$. Similar results were reported by Kaewkool (2011) and Singh et al. (2013).

\section{Gross Chemical Composition of White Soft Cheese}

Chemical analyses were assessed by determining total solids (\%), total nitrogen, fat/ DM (\%), salt/ $\mathrm{DM}$, the rate of proteolysis (SN/TN\% and NPN/ TN\%), the rate of lipolysis (TVFA), acidity and $\mathrm{pH}$. Table 3 shows that white brined soft cheese containing rice bran oil at concentrations of 0.1 and $0.2 \%$ had the highest moisture content followed by control then cheese treated with $\mathrm{BHA}$ at ratio of $200 \mathrm{ppm}$. The moisture content of all cheese treatments were significantly $(\mathrm{P} \leq$ $0.05)$ decreased during storage period for four months at room temperature $\left(25 \pm 1^{\circ} \mathrm{C}\right)$.

The decrease in moisture content of cheeses along the storage period may be due to the curd concentration and whey expulsion resulting from acid development during the storage period. Similar results were reported by Salem et al. (2010).

Table 3 shows the fat content in white soft cheese made with full cream milk (6\% fat) as affected by addition of rice bran oil at different concentrations. It could be observed that the Fat/DM content of experimental cheese samples increased significantly $(\mathrm{P} \leq 0.05)$ up to the end of storage period depending on the loss of moisture. Rice bran oil fortified cheese at different concentrations showed higher fat contents compared with other treatments. Similar results were reported by Abd El-Aziz et al. (2012) who manufacture soft cheese using ginger extract as natural antioxidant.
The salt/DM of all cheese treatments increased with the progress in storage period (Table 3). This could be due to the loss in water as a result of water exudation during pickling which in turn lead to a more salt concentration. Similar results were reported by Salem et al. (2010).

There was a significantly increasing trend $(\mathrm{P}$ $\leq 0.05)$ in titratable acidity of all cheese treatments throughout the storage period. It was observed that control cheese and BHA fortified cheese $(\mathrm{C}$ and $\mathrm{C} 1)$ had higher titratable acidity than other treatments, followed by rice bran oil fortified cheese. This may be due to higher antimicrobial activity of rice bran oil (Bardrunia, et al., 2013 ; Friedman, 2013). The trend of the changes in $\mathrm{pH}$ values of all treatments was opposite to that of titratable acidity (Table 4). $\mathrm{PH}$ values decreased in all treatments with the progress in storage period. Similar results were reported by Abd El-Aziz et al. (2012) .

Table 4 shows that TN\% content of cheese samples slightly increased up to the end of storage period. There were no significant differences in TN\% along with the storage period this may be due to high protein content and lower proteolysis in all treatments. Similar results were reported by Salem et al. (2010).

\section{The Rate of Proteolysis}

Soluble nitrogen content (as a percentage of total nitrogen, $\mathrm{SN} / \mathrm{TN} \%$ ) of cheese samples during storage are shown in Table 5. Cheese containing rice bran oil had the highest (SN/TN\%) during storage period compared with other treatments. (SN/TN\%) content in cheese samples had significant differences between control and other treatments along with the storage period which might be attributed to the differences in moisture content. The increase in soluble nitrogen content in all cheese samples throughout storage period may be due to the breakdown of protein. Similar results were reported by Salem et al. (2010) and Ramadan et al. (2014)

Differences in non-protein nitrogen content as a percentage of total protein (NPN/TN\%) of cheese samples during storage period are presented in Table 5. Generally, (NPN/TN\%) content of cheese significantly increased with 
Table 2. Content of the individual phenolic compounds in rice bran oil as determined by HPLC

\begin{tabular}{lc}
\hline Test item & Rice bran oil (mg/ 100 g) \\
\hline $\boldsymbol{\alpha}$-tocoferol & 5.48 \\
$\boldsymbol{\beta}$-tocoferol & $\mathrm{ND}$ \\
$\boldsymbol{\gamma}$-tocoferol & 2.49 \\
$\boldsymbol{\delta}$-tocoferol & $\mathrm{ND}$ \\
$\boldsymbol{\alpha}$-tocotrienol & 0.99 \\
$\boldsymbol{\beta}$-tocotrienol & $\mathrm{ND}$ \\
$\boldsymbol{\gamma}$-tocotrienol & 78.40 \\
$\boldsymbol{\delta}$-tocotrienol & 4.23 \\
\hline
\end{tabular}

$\mathrm{ND}=$ Not Detected

Table 3. Chemical analyses of white soft cheese as affected by adding rice bran oil during storage at $25 \pm 1^{\circ} \mathrm{C}$ for four months

\begin{tabular}{|c|c|c|c|c|c|c|c|c|c|c|c|c|c|c|c|}
\hline \multirow[t]{3}{*}{ Sample } & \multicolumn{15}{|c|}{ Storage period (month) } \\
\hline & \multicolumn{5}{|c|}{ Moisture (\%) } & \multicolumn{5}{|c|}{ Fat/DM (\%) } & \multicolumn{5}{|c|}{ Salt/DM (\%) } \\
\hline & Fresh & 1 & 2 & 3 & 4 & $\mathbf{0}$ & 1 & 2 & 3 & 4 & $\mathbf{0}$ & 1 & 2 & 3 & 4 \\
\hline $\mathbf{C}$ & $62.02 \mathrm{c}$ & $58.4 \mathrm{c}$ & $56.24 c$ & $53.12 \mathrm{c}$ & $51.2 \mathrm{c}$ & 40.02 & 41.82 & $43.87 \mathrm{c}$ & $45.68 \mathrm{c}$ & $48.15 \mathrm{c}$ & $14.13 b$ & $14.80 \mathrm{a}$ & 15.84 & $16.58 \mathrm{a}$ & $8.12 \mathrm{a}$ \\
\hline $\mathrm{C1}$ & $61.98 \mathrm{~d}$ & $58.2 \mathrm{~d}$ & $56.20 \mathrm{~d}$ & $53.02 \mathrm{~d}$ & $51.14 \mathrm{~d}$ & 40.50 & 41.86 & $44.52 b$ & $45.12 d$ & $48.30 \mathrm{~b}$ & $14.25 \mathrm{a}$ & $14.75 a$ & 15.75 & $16.45 \mathrm{~b} 1$ & 16.93b \\
\hline $\mathbf{T 1}$ & $62.40 \mathrm{~b}$ & $58.70 \mathrm{~b}$ & $56.42 \mathrm{~b}$ & $53.50 \mathrm{~b}$ & $51.60 \mathrm{~b}$ & 41.50 & 42.37 & $45.13 \mathrm{a}$ & $46.06 \mathrm{~b}$ & $48.61 \mathrm{a}$ & $13.53 \mathrm{c}$ & $13.73 \mathrm{c}$ & 14.20 & $14.87 \mathrm{~d} 1$ & $15.20 \mathrm{~d}$ \\
\hline $\mathbf{T} 2$ & $62.46 \mathrm{a}$ & $58.82 \mathrm{a}$ & $56.60 \mathrm{a}$ & $53.68 \mathrm{a}$ & $51.72 \mathrm{a}$ & 41.66 & 42.28 & $45.14 \mathrm{a}$ & $46.63 a$ & $48.15 \mathrm{c}$ & $13.32 d$ & $13.82 \mathrm{~b}$ & $14.30 c$ & $14.91 \mathrm{c}$ & $15.48 \mathrm{c}$ \\
\hline
\end{tabular}

Means with the same letter are not significantly different

C: Control white soft cheese

$\mathrm{C}_{1}$ : White soft cheese treated with $200 \mathrm{ppm}$ BHA

$\mathrm{T}_{1}$ : White soft cheese treated with $0.1 \%$ rice bran oil. $\mathrm{T}_{2}$ : White soft cheese treated with $0.2 \%$ rice bran oil

Table 4. Chemical analyses of white soft cheese as affected by adding rice bran oil during storage at $25 \pm 1^{\circ} \mathrm{C}$ for four months

\begin{tabular}{|c|c|c|c|c|c|c|c|c|c|c|c|c|c|c|c|}
\hline \multirow[t]{3}{*}{ Sample } & \multicolumn{15}{|c|}{ Storage period (month) } \\
\hline & \multicolumn{5}{|c|}{ Acidity (\%) } & \multicolumn{5}{|c|}{ pH value } & \multicolumn{5}{|c|}{$\overline{T N(\%)}$} \\
\hline & Fresh & 1 & 2 & $\overline{3}$ & 4 & $\overline{\mathbf{0}}$ & 1 & 2 & 3 & 4 & $\overline{0}$ & 1 & 2 & 3 & 4 \\
\hline $\bar{C}$ & $0.25 \mathrm{a}$ & $0.85 a$ & $1.46 \mathrm{a}$ & $1.74 \mathrm{a}$ & $2.20 \mathrm{a}$ & $5.5 b$ & $4.52 b$ & $4.38 \mathrm{~b}$ & $4.32 \mathrm{a}$ & $\overline{4.21 \mathrm{a}}$ & $2.42 \mathrm{~b}$ & $2.50 \mathrm{a}$ & $2.72 b$ & $2.84 b$ & $2.92 b$ \\
\hline $\mathrm{C1}$ & $0.24 \mathrm{a}$ & $0.83 b$ & $1.42 \mathrm{~b}$ & $1.70 \mathrm{~b}$ & $2.14 \mathrm{~b}$ & $5.5 \mathrm{~b}$ & $4.52 b$ & $4.40 \mathrm{a}$ & $4.33 \mathrm{a}$ & $4.20 \mathrm{a}$ & $2.40 \mathrm{c}$ & $2.46 \mathrm{c}$ & $2.68 \mathrm{~d}$ & $2.80 \mathrm{~d}$ & $2.88 \mathrm{~d}$ \\
\hline T1 & $0.20 \mathrm{bc}$ & $0.80 \mathrm{c}$ & $1.38 \mathrm{c}$ & $1.64 \mathrm{c}$ & $1.98 \mathrm{c}$ & $5.70 \mathrm{a}$ & $4.50 \mathrm{a}$ & $4.38 b$ & $4.30 \mathrm{ab}$ & $4.18 \mathrm{~b}$ & $2.44 \mathrm{a}$ & $2.48 b$ & $2.74 \mathrm{a}$ & $2.88 \mathrm{a}$ & $2.94 \mathrm{a}$ \\
\hline $\mathbf{T 2}$ & $0.20 \mathrm{bc}$ & $0.80 \mathrm{c}$ & $1.36 \mathrm{~d}$ & $1.62 \mathrm{~d}$ & $1.96 \mathrm{~d}$ & $5.70 \mathrm{a}$ & $4.50 \mathrm{a}$ & $4.36 \mathrm{c}$ & $4.28 \mathrm{~b}$ & $4.16 \mathrm{c}$ & $2.40 \mathrm{c}$ & $2.44 d$ & $2.70 \mathrm{c}$ & $2.82 \mathrm{c}$ & $2.90 \mathrm{c}$ \\
\hline
\end{tabular}

Means with the same letter are not significantly different

C: Control white soft cheese

$\mathrm{T}_{1}$ : White soft cheese treated with $0.1 \%$ rice bran oil.
$\mathrm{C}_{1}$ : White soft cheese treated with $200 \mathrm{ppm}$ BHA

$\mathrm{T}_{2}$ : White soft cheese treated with $0.2 \%$ rice bran oil 
Table 5. Proteolysis and lipolysis of white soft cheese as affected by adding rice bran oil during storage at $25 \pm 1^{\circ} \mathrm{C}$ for four months

\begin{tabular}{|c|c|c|c|c|c|c|c|c|c|c|c|c|c|c|c|}
\hline \multirow[t]{3}{*}{ Sample } & \multicolumn{15}{|c|}{ Storage period (month) } \\
\hline & \multicolumn{5}{|c|}{ SN/TN\% } & \multicolumn{5}{|c|}{ NPN/TN\% } & \multicolumn{5}{|c|}{ TVFA (ml 0.1 N NaOH/100g) } \\
\hline & Fresh & 1 & 2 & 3 & 4 & $\mathbf{0}$ & 1 & 2 & 3 & 4 & $\mathbf{0}$ & 1 & 2 & 3 & 4 \\
\hline $\mathbf{C}$ & $4.95 \mathrm{c}$ & $10.8 \mathrm{c}$ & $17.64 \mathrm{c}$ & $21.83 \mathrm{c}$ & $28.76 \mathrm{c}$ & $3.71 \mathrm{c}$ & $5.60 \mathrm{c}$ & $7.72 \mathrm{c}$ & $8.85 \mathrm{c}$ & $9.64 \mathrm{c}$ & $9.4 \mathrm{c}$ & $14.6 \mathrm{c}$ & $22.4 \mathrm{c}$ & $24.3 \mathrm{c}$ & $29.2 \mathrm{c}$ \\
\hline C1 & $4.16 \mathrm{~d}$ & $9.75 \mathrm{~d}$ & $16.79 d$ & $21.42 \mathrm{~d}$ & $28.47 \mathrm{~d}$ & $3.33 \mathrm{~d}$ & $4.87 \mathrm{~d}$ & $6.71 d$ & $8.57 \mathrm{~d}$ & $9.72 b$ & $9.2 \mathrm{~d}$ & $14.3 \mathrm{~d}$ & $22.2 \mathrm{~d}$ & $24.3 \mathrm{c}$ & $29.1 \mathrm{c}$ \\
\hline T1 & $5.41 \mathrm{~b}$ & $11.16 \mathrm{~b}$ & $17.87 b$ & $22.65 \mathrm{a}$ & $29.30 \mathrm{~b}$ & $3.41 \mathrm{~b}$ & $5.83 b$ & $7.93 b$ & $8.95 b$ & $10.07 \mathrm{a}$ & $12.5 b$ & $17.6 \mathrm{~b}$ & $25.5 b$ & $28.6 b$ & $32.9 \mathrm{~b}$ \\
\hline $\mathbf{T 2}$ & $5.58 \mathrm{a}$ & $11.33 \mathrm{a}$ & $18.20 \mathrm{a}$ & $22.29 b$ & $29.86 a$ & $4.31 \mathrm{a}$ & $7.50 \mathrm{a}$ & $8.80 \mathrm{a}$ & $9.77 \mathrm{a}$ & $10.07 \mathrm{a}$ & $12.7 \mathrm{a}$ & $17.8 \mathrm{a}$ & $25.7 \mathrm{a}$ & $28.8 \mathrm{a}$ & $33.2 \mathrm{a}$ \\
\hline
\end{tabular}

Means with the same letter are not significantly different

C: Control white soft cheese

$\mathrm{C}_{1}$ : White soft cheese treated with $200 \mathrm{ppm}$ BHA

$\mathrm{T}_{1}$ : White soft cheese treated with $0.1 \%$ rice bran oil.

$\mathrm{T}_{2}$ : White soft cheese treated with $0.2 \%$ rice bran oil

the progress in storage period. Cheese made with rice bran oil had the highest (NPN/TN\%) content compared with other treatments. Similar results were reported by Salem et al. (2010), Abd El-Aziz et al. (2012) and Ramadan et al. (2014).

\section{The Rate of Lipolysis}

Table 5 shows the changes in total volatile fatty acids (TVFA) of soft cheese samples. There were significant differences in TVFA content of cheese as compared with control when fresh and during the storage period, which could be attributed to lipolysis of fat and the higher rate of proteolysis and formation free amino acids which could be converted to volatile fatty acids through specific metabolic pathways (Nakae and Elliott, 1965). Rice bran oil cheese had the highest TVFA content during storage than other treatments. Similar results were reported by Abd El-Aziz et al. (2012).

\section{Oxidative Stability}

\section{Peroxide values (PV)}

Results presented in Table 7 shows that cheese made with rice bran oil had the lower peroxide values than control and BHA cheese. On the other hand cheese made with rice bran oil $(0.2 \%)$ had low peroxide values than control and BHA cheeses, when fresh and during the storage period.
The lower peroxide values of cheeses fortified with rice bran oil than control cheese is may be due to antioxidant activity of rice bran oil (Singh et al., 2013). The peroxide values increased significantly in different experimental cheeses as well as control with extended storage period up to the end of storage period. The obtained results are similar to those reported by Olmedo et al. (2013).

\section{Acid value (AV)}

As storage period progressed, the acid value (AV) increased gradually in all treatments as shown in Table 7. The AV of control cheese was significantly higher than that of experimental cheese and this may be due to the extensive fat hydrolysis and liberation of free fatty acids, which cause gradual increase in rancidity during storage. Control cheese had the highest AV followed by BHA treated cheese (C1) and finally rice bran oil fortified- cheese. The obtained results are similar to those reported by Abd El-Aziz et al. (2012) and Olmedo et al. (2013).

\section{TBA Values}

The trend of the changes in TBA values of all treatments was opposite to that of acid values (Table 7). TBA values increased in all treatments with the progress in storage period. The obtained results are similar to those reported by Azzam (2007). 


\section{Microbiological Examinations}

\section{Total bacterial count}

Table 6 shows the differences in total bacterial counts of cheese, there were significant differences in viable bacterial count between control cheese and other cheese samples made with natural antioxidant. The results indicated that total bacterial count gradually increased till the first month of pickling period then decreased slightly up to the end of this period. Similar results were reported by kebary et al. (2015), who reported that during the storage of cheese, the total bacterial counts slightly increased during the first period of storage, and then gradually decreased till the end of the storage period. This could be attributed to the development of acidity in cheese. The obtained results also showed that control and BHA cheeses had higher total bacterial count than rice bran oil fortified cheese. This might be due to the antimicrobial activity of rice bran oil (Bardrunia et al., 2013; Friedman, 2013).

\section{Moulds and Yeasts and Coliform Count}

Moulds and yeasts began to appear after 2 month of storage in control and BHA cheese, however, they were only observed in rice bran oil-fortified cheese throughout the storage period. Rice bran oil is known to contain several compounds such as tocopherols and tocotrinols which possess antimicrobial activity against food spoilage organisms (Bardrunia et al., 2013; Friedman, 2013).
Coliforms were not detected in all cheese treatments either when fresh or during the storage period. This may be due to the high hygienic condition during the preparation and the development in the acidity in cheese during storage period. The obtained results are similar to those reported by El-Gazzar (1993), also obtained results are similar to those reported by Olmedo et al. (2013).

\section{Organoleptic Properties}

The average score points given for appearance, body characteristics and flavour of white soft cheese as affected by adding natural antioxidant are presented in Table 8 . The results showed that there were significant differences between the control and all treatments when fresh and during storage period.Rice bran oil fortified cheese recorded the highest scores in sensory evaluation, and cheese made with rice bran oil at ratio of $(0.2 \%)$ showed better flavour intensity and body characteristics than other cheeses.

Also, results showed that cheese made with rice bran showed similar score for appearance compared with other cheese treatments.It found that all additives improved cheese properties and over all acceptability.Also, organoleptic properties of all cheese treatments were improved by the progress of storage period until the end of storage. The obtained results are similar to those reported by Azzam (2007) Bandyopadhyay et al. (2008).

Table 6. Microbiological examination of white soft cheese as affected by adding rice bran oil during storage at $25 \pm 1^{\circ} \mathrm{C}$ for four months

\begin{tabular}{|c|c|c|c|c|c|c|c|c|c|c|c|c|c|c|c|}
\hline \multirow[t]{3}{*}{ Sample } & \multicolumn{15}{|c|}{ Storage period (month) } \\
\hline & \multicolumn{5}{|c|}{ Total count $(\mathrm{cfu} / \mathrm{g}) 1^{3}$} & \multicolumn{5}{|c|}{ Yeast and mould (cfu/g)10 1} & \multicolumn{5}{|c|}{$E$. coli count $(\mathrm{cfu} / \mathrm{g}) 1^{1}$} \\
\hline & $\mathbf{0}$ & 1 & 2 & 3 & 4 & $\mathbf{0}$ & 1 & 2 & 3 & 4 & $\mathbf{0}$ & 1 & 2 & 3 & 4 \\
\hline$\overline{\mathbf{C}}$ & 130 & 162 & 112 & 86 & 18 & ND & ND & 5 & 15 & 22 & 5 & ND & ND & ND & $\mathrm{ND}$ \\
\hline C1 & 112 & 130 & 80 & 20 & 8 & ND & ND & 2 & 12 & 17 & 2 & ND & ND & ND & ND \\
\hline T1 & 10 & 14 & 9 & 6 & 4 & ND & ND & ND & 5 & 8 & ND & ND & ND & ND & ND \\
\hline $\mathbf{T} 2$ & 8 & 12 & 5 & 5 & 2 & ND & ND & ND & ND & ND & ND & ND & ND & ND & ND \\
\hline
\end{tabular}

$\mathrm{ND}=$ Not detected

C: Control white soft cheese

$\mathrm{T}_{1}$ : White soft cheese treated with $0.1 \%$ rice bran oil.
$\mathrm{C}_{1}$ : White soft cheese treated with $200 \mathrm{ppm}$ BHA

$\mathrm{T}_{2}$ : White soft cheese treated with $0.2 \%$ rice bran oil 
Table 7. Oxidative stability of white soft cheese as affected by rice bran oil during storage at 25 $\pm 1^{\circ} \mathrm{C}$ for four months

\begin{tabular}{|c|c|c|c|c|c|c|c|c|c|c|c|c|c|c|c|}
\hline \multirow[t]{3}{*}{ Sample } & \multicolumn{15}{|c|}{ Storage period (month) } \\
\hline & \multicolumn{5}{|c|}{ Peroxide value (meq/kg) } & \multicolumn{5}{|c|}{ Acid value (mg KOH/g oil) } & \multicolumn{5}{|c|}{ TBA value(O.D 532 nm) } \\
\hline & Fresh & 1 & 2 & 3 & 4 & Fresh & 1 & 2 & 3 & 4 & Fresh & 1 & 2 & 3 & 4 \\
\hline $\bar{C}$ & $4.92 \mathrm{a}$ & $7.40 \mathrm{a}$ & $14.52 \mathrm{a}$ & $20.3 \mathrm{a}$ & $25.2 \mathrm{a}$ & $0.76 \mathrm{a}$ & $1.22 \mathrm{a}$ & $2.45 \mathrm{a}$ & $3.12 \mathrm{a}$ & $4.24 a$ & $0.139 \mathrm{a}$ & $0.182 \mathrm{a}$ & $0.230 \mathrm{a}$ & $0.324 \mathrm{a}$ & $0.392 \mathrm{a}$ \\
\hline C1 & $4.80 \mathrm{~b}$ & $7.12 b$ & $14.15 b$ & $19.6 \mathrm{~b}$ & $24.4 \mathrm{~b}$ & $0.74 \mathrm{~b}$ & $1.18 \mathrm{~b}$ & $2.12 b$ & $2.9 \mathrm{~b}$ & $4.08 \mathrm{~b}$ & $0.139 b$ & $0.167 \mathrm{~b}$ & $0.210 \mathrm{~b}$ & $0.312 b$ & $0.32 b$ \\
\hline T1 & $4.72 \mathrm{c}$ & $6.42 \mathrm{c}$ & $9.36 \mathrm{c}$ & $10.14 \mathrm{c}$ & $12.62 \mathrm{c}$ & $0.68 b c$ & $0.98 \mathrm{c}$ & $1.62 \mathrm{c}$ & $1.34 \mathrm{c}$ & $1.82 \mathrm{c}$ & $0.136 \mathrm{ab}$ & $0.160 \mathrm{c}$ & $0.170 \mathrm{c}$ & $0.182 \mathrm{c}$ & $0.192 \mathrm{c}$ \\
\hline $\mathbf{T 2}$ & $4.50 \mathrm{~d}$ & $5.18 \mathrm{~d}$ & $7.86 \mathrm{~d}$ & $9.20 \mathrm{~d}$ & $11.50 \mathrm{~d}$ & $0.64 \mathrm{~d}$ & $0.72 \mathrm{~d}$ & $0.86 \mathrm{~d}$ & $1.00 \mathrm{~d}$ & $1.14 \mathrm{~d}$ & $0.134 b$ & $0.140 \mathrm{~d}$ & $0.160 \mathrm{~d}$ & $0.174 \mathrm{~d}$ & $0.184 d$ \\
\hline
\end{tabular}

Means with the same letter are not significantly different

C: Control white soft cheese $\quad \mathrm{C}_{1}$ : White soft cheese treated with 200 ppm BHA

$\mathrm{T}_{1}$ : White soft cheese treated with $0.1 \%$ rice bran oil. $\mathrm{T}_{2}$ : White soft cheese treated with $0.2 \%$ rice bran oil

Table 8. Organoleptic properties of white soft cheese as affected by adding rice bran oil during storage at $25 \pm 1^{\circ} \mathrm{C}$ for four months

\begin{tabular}{|c|c|c|c|c|c|c|c|c|c|c|c|c|c|c|c|c|c|c|c|c|}
\hline \multirow[t]{3}{*}{ Sample } & \multicolumn{20}{|c|}{ Storage period (month) } \\
\hline & \multicolumn{5}{|c|}{ Appearance (10) } & \multicolumn{5}{|c|}{ Flavour (50) } & \multicolumn{5}{|c|}{ Body and texture (40) } & \multicolumn{5}{|c|}{ Total (100) } \\
\hline & $\overline{\mathbf{0}}$ & 1 & 2 & 3 & 4 & $\mathbf{0}$ & 1 & 2 & 3 & 4 & $\mathbf{0}$ & 1 & 2 & 3 & 4 & $\mathbf{0}$ & 1 & 2 & 3 & 4 \\
\hline $\bar{C}$ & 7 & 8 & 8 & 9 & 8 & 42 & 44 & 44 & 46 & 46 & 37 & 39 & 39 & 40 & 40 & $86 a b$ & $91 \mathrm{a}$ & $91 \mathrm{ab}$ & $95 \mathrm{a}$ & $94 \mathrm{ab}$ \\
\hline C1 & 7 & 8 & 8 & 9 & 8 & 40 & 42 & 43 & 43 & 45 & 36 & 38 & 40 & 40 & 40 & $83 \mathrm{bc}$ & $88 b$ & $91 \mathrm{ab}$ & $92 \mathrm{ab}$ & $93 \mathrm{ab}$ \\
\hline T8 & 7 & 8 & 8 & 9 & 8 & 43 & 45 & 45 & 46 & 47 & 38 & 38 & 40 & 40 & 40 & $88 \mathrm{a}$ & $91 \mathrm{a}$ & $91 \mathrm{ab}$ & $95 \mathrm{a}$ & $95 \mathrm{a}$ \\
\hline T9 & 7 & 7 & 8 & 9 & 7 & 42 & 43 & 44 & 46 & 46 & 39 & 39 & 40 & 40 & 40 & $88 \mathrm{a}$ & $89 \mathrm{ab}$ & $92 \mathrm{a}$ & $95 \mathrm{a}$ & $93 \mathrm{ab}$ \\
\hline
\end{tabular}

Means with the same letter are not significantly different

C: Control white soft cheese

$\mathrm{C}_{1}$ : White soft cheese treated with 200 ppm BHA

$\mathrm{T}_{1}$ : White soft cheese treated with $0.1 \%$ rice bran oil. $\mathrm{T}_{2}$ : White soft cheese treated with $0.2 \%$ rice bran oil

\section{Conclusion}

It is notable that rice bran oil has a strong antioxidant capacity relatively comparable to the activity of BHA. Therefore, it can be used as natural antioxidant in manufacturing white soft cheese to improve its oxidative stability during storage.

\section{REFERENCES}

AOAC (1990). In Official Methods and Recommended Practices of the American Oil Chemists Society $\left(4^{\text {th }}\right.$ Ed.). Champaign: American Oil Chemists' Soc.
AOAC (2007). Association of Official Analytical Chemists-Official Method of Analysis (18 ${ }^{\text {th }}$ Ed.), Benjamin Franklin Station Washington, DC, USA.

Abd El-Aziz, M., H.S.S. Mohamed and F.L. Seleet (2012). Production and evaluation of soft cheese fortified with Ginger extract as functional dairy food. Poi. J. Food Nut. Sci., 62 (2): 77-83.

Abdulla, A.E.M., S.M. Darwish, E.H.E. Ayad and R.M. El-Hamahmy (2007). Egyptian mango by product 2: Antioxidant and antimicrobial activities of extracts and oil from mango seed kernel. Food Chem., 103: 1141-1152. 
Abidi, S.L. (2003). Tocol-derived minor constituents in selected plant seed oils. J. Ame. Oil Chem. Soc., 80 (4): 327- 333.

Ajila, C.M., R.A. Naidu, S.G. Bhat and U.J.S. Prasada Rao (2007). Bioactive compounds and antioxidant potential of mango peel extract. Food Chem., 105 (3): 982 - 988.

Akiri, S.V.C.R., G.R. Sareddy, P.B. Phanithi and R.R. Attipalli (2010). The antioxidant and antiproliferative activities of methanolic extracts from Njavara rice bran, BMC Complementary and Alternative Med., 10 (4): 1 - 9 .

Azzam, M.A. (2007). Effect of partial replacement of milk fat with vegetable oils on the quality of processed cheese spreads. Egypt. J. Dairy Sci., 35: 87-95.

Bandyopadhyay, M., R. Chakraborty and U. Raychaadhuri (2008). Antioxidant activity of natural plant sources in dairy dessert (sandesh) under thermal treatment. LWT Food Sci. and Technol., 41 (5) : 816 - 825.

Bandyopadhyay, M., R. Chakraborty and U. Raychaudhuri (2007). A process for preparing a natural antioxidant enriched dairy products (Sandesh). LWT-Food Sci. Technol., 40: 842-851.

Bardrunia, S., R.D. Chandrikap and P. Jecvitha (2013). Isolation of oxylipin from rice bran as antibacterial principle against Pseudomonus aeruginosa. Int. J. Res. Studies in Biosci. (IJRSB). 1(1):1-7.

Bopitiya, D. and T. Madhujith (2014). Antioxidant potential of rice bran oil prepared from red and white rice. Tropical Agric. Res., 26 (1): 1 -11 .

Egan, H., R.S. Kirk and R. Sawyer (1981). Pearson's Analysis of Foods, $8^{\text {th }}$ Ed. Churchill Livingstone, Edinburgh London Melbourne and New York, 536-538.

El-Gazzar, F.E. (1993). Fate of Escherichia coli 0157:H7 during manufacture and storage of Yoghurt and Domiati cheese. Assiut. J. Agric. Sic., 24 : 185-196.

Fahmi, A.H. and H.A. Sharara (1950). Studies on Egyptian Domiati cheese. J. Dairy Res., 17: 312-318.
Friedman, M. (2013). Rice brans, rice bran oils, and rice hulls: composition, food and industrial uses, and bioactivities in humans, animals, and cells. J. Agric. and Food Chem., 61 (45): 10626-10641.

Goupy, P., M. Hugues, P. Boivin and M.J. Amiot (1999). Antioxidant and activity of barley (Hordeum vulgare) and malt extracts and of isolated phenolic compounds. J. Sci. Food Agric., 79 : 1625-1634.

Gulcin, I., O.I. Kufrevioglu, M. Oktay and M.E. Buyukokuroglu (2004). Antioxidant, antimicrobial, antiulcer and analgesic activities of nettle (Urticadioica L.). J. Ethnopharmacol., 90: 205-215.

Hatano, T., H. Kagawa, T. Yasuhara and T. Okuda (1988). Two new flavonoids and other constituents in licorice root: their relative astringency and radical scavenging effects. Chem. Pharm. Bull., 36: 2090-2097.

Houghtby, G.A. and E.K. Matuin (1992). Microbiological count methods. In: Standard Methods for the Examination of Dairy Products Marshall, T.R. (Editor) American Public Health Association, Washington, DC., USA.

Innocente, N. (1997). Free amino acids and water-soluble nitrogen as ripening indices in Montasio cheese. Lait, 77: 359-369.

Jang, H.A., P.K. Young and S.K. Hak (2012). Effect of natural antioxidants on the lipid oxidation of microencapsulated seed oil. Food Control, 23: 528 - 534.

Kaewkool, P. (2011). Characterization of cold pressed organic rice bran oil. As. J. Food Ag. Ind., 4 (01): $16-21$

Kebary, K.K., H.A. El-Shazly and I.T. Youssef (2015). Quality of Probiotic UF Domiati Cheese made by Lactobacillus rhamnosus. Int. J. Curr. Microbiol. App. Sci., 4 (7): $647-$ 656.

Keeny, P.G. (1971). A guide to controlling oxidation in butter creams. Candy and Snack Industry, 136 (7): 68-74.

Kosikowski, F.V. (1982). Cheese and Fermented Milk Foods, $2^{\text {nd }}$ Ed. F.V. Kosikowski and Associates, Brooktondale, New York, 573 574. 
Kristensen, D., E. Hansen, A. Arndal, R.A. Trinderup and L.H. Skibsted (2001). Influence of light and temperature on the colour and oxidative stability of processed cheese. Int. Dairy J., 11: 837-843.

Marshall, R.T. (1992). Standard Methods for the Examination of Dairy Products. $16^{\text {th }} \mathrm{Ed}$. American Public Health Association (APHA), Washington, DC, USA, 158.

Mattila, P., J. Astola and J. Kumpulanien (2000). Determination of flavonoids in plant material by HPLC with diode-array and electro-array detections. J. Agric. Food Chem., 48 : 58345841.

Nakae, J. and J.A. Elliott (1965). Production of volatile fatty acids by some lactic acid bacteria. J. Dairy Sci., 48 : 273.

Olmedo, R., V. Nepote and R. Nelson (2013). Preservation of sensory and chemical properties in flavoured cheese prepared with cream cheese base using oregano and rosemary essential oil. LWT. Food Sci. and Technol., (53): 409 - 417.

Pappas, C.P., E. Kondly, L.P. Voustsinas and H. Mallatou (1996). Effect of starter level, draining time and aging on the physicochemical, organoleptic and rheological properties of Feta cheese. J. Soc. Dairy Tech., 49: 73-78.

Patel, M. and S.N. Naik (2004). Gammaoryzanol from rice bran oil: A review, J. Sci. and Indust. Res., 63: 569-578.

Pengkumsri, N., C. Chaiyasut, B.S. Sivamaruthi, C. Saenjum, S. Sirilun, S. Peerajan, P. Suwannalert, S. Sirisattha, K. Chaiyasut and P. Kesika (2015). The influence of extraction methods on composition and antioxidant properties of rice bran oil. Food Sci. Technol., Campinas, 35(3): 493-501.

Ramadan, M.F., S.A. Mahgoub and K.M. ElZahar (2014). Soft cheese supplemented with black cumin oil: Impact on food borne pathogens and quality during storage. Saudi J. Biol. Sci., 21: 280-288

SAS (1998). User's guide.6. 12 end statistical Analysis System Institute Inc. Cary NC 27511-8000, USA.

Salem, S.A., I.E. Gad El-Ral and W.S. ElSharaihy (2010). Improving the quality of fat soft cheese (Domiati) by incorporation whey protein concentrate. Proc. $11^{\text {th }}$ Egyptian conf. Dairy. Sci. and Technol., 145-162.

Sarmento, C.M.P., S.R.S. Ferreira and H. Hense (2006). Supercritical fluid extraction (SFE) of rice bran oil to obtain fractions enriched with tocopherols and tocotrienols. Brazilian J. Chem. Eng.. 23, 2: 243 - 249.

Singh, V.K., L.A. Beattie and T.M. Seed (2013). Vitamin E: tocopherols and tocotrienols as potential radiation countermeasures. J. Rad. Res., 54 (6): 973-988.

Škerget, M., P. Kotnik, M. Hadolin, A. RižnerHraš, M. Simonič and Z. Knez (2005). Phenols, proanthocyanidins, flavones and flavonols in some plant materials and their antioxidant activities. Food Chem., 89: 191198.

Yean, Y.S. and J.B. Philip (2004). Antioxidant activity and phenolic content of selected fruit seeds. Food Chem., 88: 411 - 417. 


\title{
استخدام زيت رجيع الكون كمضاد طبيعي للأكسدة في صناعة الجبن الأبيض الطري
}

\author{
على عبدالرحمن عبدالجليل ـ السيد حسن عطوة

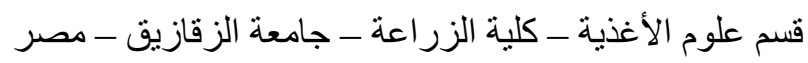

أجريت هذه الدراسة لتقدير النشاط المضاد للأكسدة ومحتوى المركبات الفينولية لزيت نخالة الأرز (رجيع الكون)

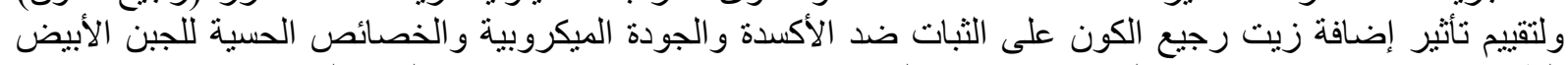

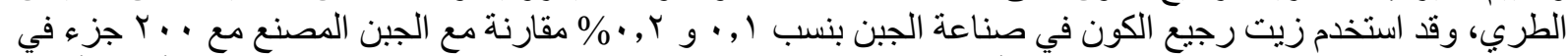

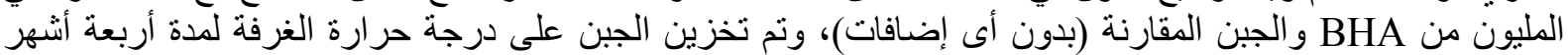

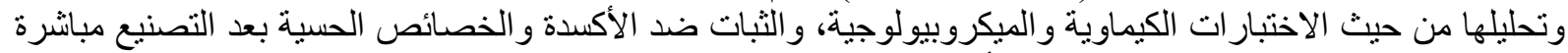

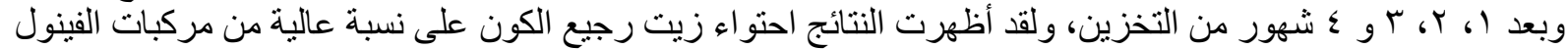

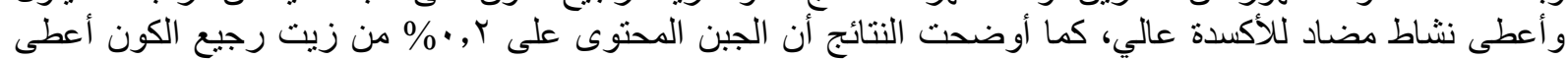

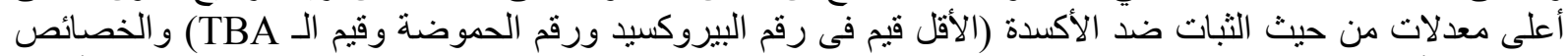

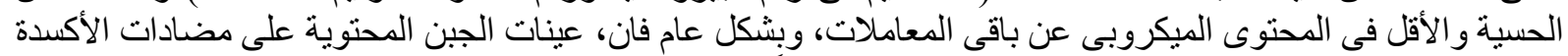

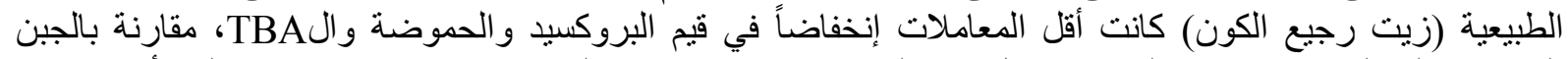

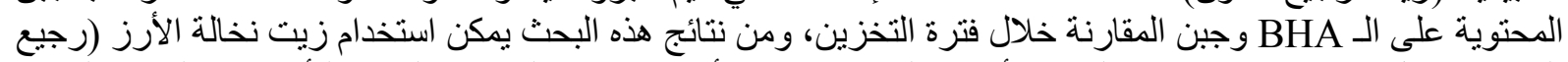

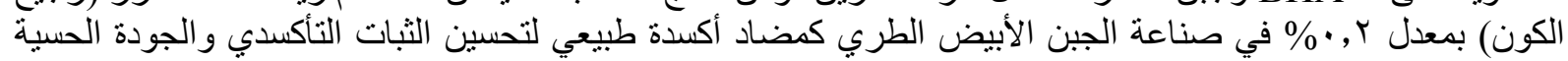

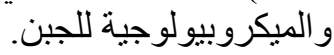

